\title{
Italy's Lega Nord: Changing Poses in a Shifting National and European landscape
}

\author{
MICHAEL LONGO \\ Victoria University, Melbourne \\ Michael.Longo@vu.edu.au
}

\begin{abstract}
This article examines changing approaches to ethnicity and nationalism of the Lega Nord (LN), a populist far-right political party in Italy, against a backdrop of growing anti-EU and anti-immigrant sentiment. The article reflects on the contexts in which populist and far right politics are taking hold in Italy and in the European Union (EU), with the LN used to illustrate this dynamic. The EU is shaping national politics in new and unexpected ways. The article concludes that the $L N$ is seizing the opportunity to recast itself in Italy by adopting a national anti-euro, anti-austerity, anti-EU project at the same time that populist parties in other member states of the EU are capitalising on deepening societal insecurity and growing opposition to the EU, the euro, immigration and EU-imposed austerity.
\end{abstract}

Keywords: European Union, immigration, Italy, Lega Nord, nationalism, populism.

\section{Introduction}

The Lega Nord (LN) - which translates as the Northern League - is Italy's far-right anti-immigration, traditionally anti-southern party, and it is currently undergoing a major transformation. Under its new leader Matteo Salvini, the LN has softened its anti-southern rhetoric, toughened its stance on European integration and the euro, and established strong ties with other far right populist parties in Europe. This rebranding is perhaps the most significant in the LN's almost 25-year history. The recent election result in the Emilia-Romagna region (on the edge of the LN's traditional heartland of Lombardy, Veneto and Piedmont), where the LN received $19.4 \%$ of the vote in the 2014 regional election, ${ }^{1}$ indicates that the LN's fortunes are improving as voters cast their disapproval in a country experiencing de-industrialisation, continuing economic malaise, unemployment and political instability. The LN emerged from the election in Emilia as the second largest party and the largest party of the right, eclipsing Silvio Berlusconi's Forza Italia (FI) party and Angelino Alfano's Nuovo Centro Destra (NCD) party. Particularly remarkable was the fact that the LN had only managed to secure $2.6 \%$ of the vote in Emilia-Romagna at the general election in $2013 .{ }^{2}$ This success is due in part to the populist campaign launched against immigration and the

\footnotetext{
${ }^{1}$ Ministero Dell'Interno Archivio Storico delle Elezioni, 2014, accessed 7 March 2015, $\mathrm{http}: / /$ elezionistorico.interno.it/index.php?tpel $=\mathrm{R} \& d t \mathrm{dt}=23 / 11 / 2014 \&$ tpa $=\mathrm{I} \& \mathrm{tpe}=\mathrm{R} \& \mathrm{levo}=\mathrm{O} \& \mathrm{levsuto}=0 \& \mathrm{lev} 1=8$ \&levsut1 $=1 \&$ ne $1=8 \&$ eso $=$ S\&es $1=S \& m s=S$

${ }^{2}$ Ministero Dell'Interno Archivio Storico delle Elezioni, 2013, accessed 7 March 2015,

$\mathrm{http}: / /$ elezionistorico.interno.it/index.php?tpel $=\mathrm{C} \& \mathrm{dtel}=24 / 02 / 2013 \& \mathrm{tpa}=\mathrm{I} \& \mathrm{tpe}=\mathrm{I} \& \mathrm{levO}=0 \& \mathrm{levsuto}=0 \& \mathrm{lev} 1=11$ \&levsut1 $=1 \&$ ne $1=11$ \&eso $=\mathrm{S} \& \mathrm{es} 1=\mathrm{S} \& \mathrm{~ms}=\mathrm{S}$
} 
euro. On the larger Italian stage, a general receptiveness to the problems faced by people in southern Italy marks the beginning of a transformation from a regionalist party to a far-right, anti-EU nationalist party of the variety seen in other European states.

Opportunistic by nature and tradition, the LN has identified and grasped an opportunity to expand its support base. Salvini is steering "il Carroccio" 3 southwards, venturing tentatively towards the hitherto unfathomable notion of representing citizens across the length of Italy. To be sure, calls for federalism and a greater share of taxes for the north have not been abandoned, but rather reprioritised behind presumed national concerns, such as the abandonment of the euro currency and the repatriation of national decision-making power from the European Union (EU). Salvini's exhortation to the interests of national citizens appears somewhat at odds with the slogan Prima Il nord (first the north), coined under the leadership of Roberto Maroni, current President of Lombardy and former leader of the LN. It is not uncommon now for Salvini to appeal to the residents of Naples or Palermo in expounding the LN's anti-EU and anti-immigrant policies. Salvini's overtures to the south may be inspired by political pragmatism, but they are in marked contrast to the LN's firebrand style under its founding leader, Umberto Bossi, which was characterised by the unrelenting lambasting of the southerners for most of the ills of Italy. Indeed, this new era in the LN's history may mark the transformation of the LN into a traditional far-right party of the kind seen in other parts of Western Europe. Whether political expediency and pragmatism will compel the LN to complete its metamorphosis into a national party along the lines of the French Le Front National will to a large extent determine its political pull in an increasingly anti-EU Europe. However, the party that emerges from this process will arguably no longer be the Lega Nord, as it will have lost its raison d'etre. Whether Salvini will be coaxed by European right-wing populists into completing the transformation or whether the party's true believers will obstruct a change of direction that would negate its northern focus and heritage will determine whether the LN succeeds in capturing a large share of the growing anti-EU populist vote across the breadth and length of Italy. It is unlikely that the party will willingly resume its traditional role as junior partner in future national centre-right coalition governments.

This article will trace the LN's previous efforts at mobilising anti-state forces in its northern heartland and its forays into securing support in bordering regions of Italy through means of a pragmatic construction of northern identity. History shows that border territories at the edge of Padania 4 can be brought into Padania's orbit, but that there are varying degrees of receptiveness to the LN's appeal to northern distinctiveness. The myth of a northern Italian identity has not proved as successful in attracting the high levels of support for the LN in border regions as it has in the LN's heartland. Electoral results have consistently shown lower support for the LN in areas bordering Padania's heartland, with declining support the further away the territory lies.

The article will consider the LN's current prospects for enlarging its support base against a backdrop of rising populism and anti-EU sentiment across the EU. The LN's

\footnotetext{
3 The LN is often referred to as "il carroccio". A carroccio was a four-wheeled war altar drawn by oxen and used by Italian republics in medieval times.

4 Padania is the name proposed by the LN for a future independent state comprising the regions in the Po Valley or Pianura Padana and surrounding areas. The name carries potent socio-political connotations.
} 
new "southern" accommodation phase will be shown to represent a distinct repositioning in order to widen the party's electoral appeal. This shift presages a potential new chapter in the development of contemporary Italian identity, informed by ideas and sentiments that nurture nationalism, protectionism and dichotomous visions of "us" and "them". The article concludes that while the current circumstances hold both the seeds of political growth and destruction for the LN, the LN appears to be emerging from the margins and into a position of national prominence from which it will wield considerable influence on national agendas and public policy, 5 to the detriment of pluralism and tolerance of difference.

\section{A Shifting Focus: Autonomy or Secession?}

Italy is a unitary country with features of federalism. The country has been subject to a process of decentralisation for some decades. This is an incomplete process, which includes embryonic elements of fiscal federalism. Fiscal federalism and devolution are now strongly championed by the LN, which has variously agitated for the secession of northern Italy from the rest of the country and federal autonomy. The LN's name itself - Lega Nord per l'Indipendenza di Padania - reveals aspirations that do not sit comfortably with the Italian state's essential objective of national unity. With little shared history and culture among its constituent regions, ${ }^{6}$ the LN has been described as "an example of a new and as yet under theorised form of nationalism whereby rich peripheries aspire to liberate themselves of the shackles of national solidarity" .7 This phenomenon is encouraged by globalisation. As Gold notes, by stressing economic competition, globalisation is providing a "greater incentive for wealthier regions to secede or at least bargain for more autonomy."8

The LN has had varying electoral success over the years, opportunistically manipulating its policies for maximum political effect. There have been the inevitable miscalculations, but the party has usually recovered from these relatively quickly. After a huge success at the 1996 general election, where it achieved 10.1\% of votes - as high as $\mathbf{2 9 . 3 \%}$ in Veneto and $25.5 \%$ in Lombardy 9 the Lega announced a policy for the secession of northern Italy under the name of Padania. This policy, among others, proved problematic for the party at the 1999 EP election, resulting in the loss of more than half its vote from the 1996 election. A fractured membership and agenda had led to numerous defections from the party in the lead up to the 1999 election. Since then, the LN has de-emphasised demands for secession, focusing instead on devolution and federalism, which enabled the formation of coalition government with Silvio Berlusconi. However, despite being holders of Italian ministerial posts in successive Berlusconi governments, the party's leadership has sometimes appeared to struggle to restrain its secessionist tendencies and anti-Rome rhetoric. This ability to criticise the centralised Italian bureaucracy from the corridors of power has enabled the party to maintain its populist identity as a party of protest. Zaslove rightly attributes the LN's

\footnotetext{
5 Thomas W. Gold, The Lega Nord and Contemporary Politics in Italy, Houndmills: Palgrave Macmillan, 2003, p. 130.

${ }^{6}$ The regions in the North of Italy, including the autonomous provinces of Alto-Adige, Trentino and Valle d'Aosta are no less distinctive than other regions of Italy.

7 Michael Huysseune, 'Landscapes as a Symbol of Nationhood: The Alps in the Rhetoric of the LegaNord', Nations and Nationalism, Vol.16, No. 2, 2010: p. 355 .

${ }^{8}$ Gold, 2003, p. 7.

9 Ministero Dell'Interno Archivio Storico delle Elezioni, 1996, accessed 7 March 2015,

$\mathrm{http} / / /$ elezionistorico.interno.it/index.php?tpel=C\&dtel=21/04/1996\&tpa $=\mathrm{I} \& \mathrm{tpe}=\mathrm{I} \& \mathrm{levo}=0 \& \mathrm{levsuto}=0 \& \mathrm{lev1}=7 \&$ levsut $1=1 \&$ ne $1=7 \&$ eso $=S \&$ es $1=S \& m s=S$
} 
capacity to retain its combative identity while in power to a special relationship with Berlusconi within a heterogeneous governing coalition. Thus, it was able to "attack the coalition without fearing repercussions", "keeping one foot in government while still having the other firmly planted outside government". ${ }^{10}$ The LN's ability to occupy a position between populism and pragmatism is a characterising feature of the LN's experience of government.

For the LN's founder and former leader, Umberto Bossi, the Italian national anthem, the Italian flag and other symbols of Italian national identity have often evoked derision and contempt. ${ }^{11}$ However, this has not prevented the LN's leaders from seeking and obtaining key roles in national government. Bossi occupied the role of Minister for Reform in the second and fourth Berlusconi cabinets. As this role includes the task of organising the structure of the state, the choice of Bossi, a secessionist, as Minister for Reform was a curious decision. Aprile has noted that "[a]ppointing Bossi to [this] position .... is like appointing Dracula the director of a blood bank." 12 Roma Ladrona (Rome, thief) was a common refrain during Bossi's Ministerial pursuits, and it is this almost surreal spirit of protest and pragmatism that has informed the LN's policies towards Rome, whether within or without government.

A combination of continuing dissatisfaction with central government institutions and unwillingness to endorse transfer payments to the south provides a rationale for the LN's strong advocacy for the reform of fiscal arrangements between Rome and the regions, the ultimate goal of which is the financial autonomy of Italy's twenty regions. The LN now advocates the transformation of Italy into a federal state. This policy sets it aside from other regionalist parties in Europe, which tend to demand special rights for particular regions. While its very name contains a demand for the independence of Padania, the LN is difficult to pin down in terms of ideology. Its leaders have described the party as being neither of the right nor the left. It currently espouses a Europe of the regions and identifies as "Europeanist", but is also Eurosceptical. It is pro-business but anti-globalisation. Its rhetoric is at times racist and supremacist, but it rejects claims of racism and xenophobia. Its official policies are more moderate than its rhetoric. As noted above, it is difficult to determine whether the party is truly oriented to separatism or federalism. One senses that this indeterminacy suits the party leadership, who wish to reserve the right to switch the party's policies according to current exigencies. The $\mathrm{LN}$ is constantly remaking itself to meet the fresh anxieties of its constituency, itself a shifting target.

\section{Moves Towards Decentralisation}

The Italian parliament endorsed Law 42 on fiscal federalism in $2009,{ }^{13}$ setting in motion a determined but slow move towards decentralisation. The law envisaged increased tax and spending autonomy of the regions, provinces and municipalities (among other things), but a set of legislative decrees has not yet been implemented, which means that the policy remains an empty shell. In fact, in some instances,

\footnotetext{
${ }^{10}$ Andrej Zaslove, The Re-Invention of the European Radical Right: Populism, Regionalism and the Italian Lega Nord, Montreal: McGill-Queens University Press, 2011, p. 158.

${ }^{11}$ Agnes Poirier, 'Italy's Eccentric Man of the North', The Guardian, 18 September 2009, accessed 11 February 2015, http://www.theguardian.com/commentisfree/2009/sep/17/italy-north-umberto-bossi

12 Pino Aprile, Terroni, All that Has Been Done to Ensure That The Italians of The South Became "Southerners", trans. I. M. Rosiglioni, New York: Bordighera Press, 2011, p. 298.

${ }^{13}$ Law 42 /2009 is a framework law which sets out the broad elements of reform towards fiscal federalism but leaves the implementation to a set of decrees.
} 
decentralisation appears to have been reversed. For instance, Italy's provinces have been transformed by Law 56/2014 into "institutional bodies of second level" as a prelude to their abolition. With the emergence of an economic crisis of unprecedented proportions in post-war Italy and the non-participation of the LN in successive national governments since November 2011 (when the Berlusconi government was forced to resign amid fears that Italy would be dragged into the Eurozone crisis), the process of decentralisation has lost some momentum in favour of market and workplace reforms and constitutional changes, such as the reform of the Senate. It must be said, however, that many of these changes are regarded as preliminary to the implementation of fiscal federalism.

Despite well-known Italian political peculiarities, significant regional differences and inauspicious historical antecedents, autonomy is a principle which has taken root and prospered in certain parts of Italy. ${ }^{14}$ However, at the heart of the LN's on-and-off advocacy for secession and devolution is the enduring belief (not uncommon in richer parts of many countries) that it is a gross injustice for the taxes of its people to subsidise poorer, "less deserving", parts of the country. It is beyond the scope of this paper to evaluate proposals for fiscal federalism in Italy against established federalist principles, but serious debates are yet to be had about the sharing of powers between national and sub-national governments, the sources of financing and the fiscal equalisation rules. Moreover, the persistence of divisions and antagonism between north and south acts as an impediment to the emergence of values, such as respect for the autonomy of its constituents, a preference for processes that minimise coercion, regional diversity and local participation, upon which successful decentralisation rests. ${ }^{15}$ In the light of enduring political, social and economic problems and divisions, perhaps the real issue will be whether appropriate mechanisms can be established to mediate and effectively settle conflicts in an emerging federal system in the interest of national solidarity, an equitable division of resources among the regions and the national interest generally.

\section{The Lega's promotion of a distinctive region called Padania}

Founded in 1991 as a federation of regional parties in northern and central Italy, the $\mathrm{LN}$ is now the oldest political party in Italy, having survived the collapse of the postwar political order of revolving Christian Democratic (CD) governments that characterised the first republic (1948-1992). ${ }^{16}$ The LN was a major beneficiary of the new post-1992 political order. It gained political momentum among the working class in northern Italy as its charismatic, firebrand leader, Umberto Bossi, espoused claims of a northern regional identity based on a Celtic heritage coupled with populist "anti-southern", "anti-immigrant" and "anti-Roman" rhetoric which maintained barriers between north and south and challenged the Italian state's stated objective of national unity. Its oft-repeated mantra of Roma Ladrona and its on-and-off advocacy for a separate and

\footnotetext{
${ }_{14}$ This is particularly true of Italy's two autonomous provinces with special competences - Trento and BolzanoBozen in the region of Trentino-Alto Adige/Südtirol. Alto Adige or Südtirol provides a particularly interesting case of interest accommodation in a quasi-federal system against a backdrop of cultural and linguistic diversity, while simultaneously demonstrating the dynamism of autonomy.

15 Matt Harvey, Michael Longo, Julian Ligertwood, David Babovic and Darren Parker, Study Guide Constitutional Law, Chatswood, NSW: LexisNexis Butterworths, 2014, pp. 143-144.

${ }^{16}$ The second republic was not established through constitutional amendment, but is widely reported as a defining political event. The transition from first to second republic is punctuated by the end of the cold war and the political upheaval associated with the "mani puliti" (clean hands) operation in which the Italian governing parties were implicated in widespread corruption and fraud leading to the demise of many political parties.
} 
independent Padania seemed at times to run counter to a pragmatic program of accommodation, which saw the LN participate in successive national Berlusconi governments from 1994 to 2011. However, this strategy was quite considered and purposeful. At times the national political agenda has been driven by the LN's policies: the decisions of the last Berlusconi government to turn around immigrant boats from Africa and moves towards the adoption of fiscal federalism through which more taxes were to remain in the north are two high profile examples. The more moderate elements within the LN seemed to have reached the conclusion during that phase of political manoeuvring that the LN's objectives were better pursued within the mainstream political system - and preferably in government - than on the fringes. The LN's ability to maintain its image as a credible party of protest and to differentiate itself from other parties within the governing coalition meant that it had nothing to lose.

The LN has consistently perpetuated the idea of a distinctive folkloristic and cultural tradition of a sociopolitical territory which includes part of central and all of northern Italy and which has at its heart the Po River (Padus in Latin; hence Padania), which etches a course from Piedmont in the west to the Adriatic near Venice in the east. Huysseune notes that establishing a Padanian cultural unity is problematic. ${ }^{17}$ This territory does not have an historical basis, let alone a shared culture, despite the LN's attempts to invest it with a flag (the Sun of the Alps), an anthem (the Va Pensiero chorus from Verdi's Nabucco), various emblems and an ethno-regional identity (Celtic origins, industriousness, civic responsibility and integrity). Indeed, northern virtues are commonly identified as "a sense of organization, of thrift, of entrepreneurship, a work ethic, simplicity and matter-of-factness, respect for promises given, sobriety, discretion and moderation", all of which, as Huysseune conveys, are traditionally thought by the LN to be crucially lacking in southerners. ${ }^{18}$

Most Italians believe the LN's construction of Padania is a recent invention, ${ }^{19}$ though this does not attenuate the desire for secession in certain parts of northern Italy. Based on its populist, anti-southern and anti-immigrant rhetoric, verging sometimes on xenophobia or racism, it is easy to conclude that the construction of Padania aims towards divisiveness, differentiation and exclusion. The superiority of the north is "systematically associated with its modernity, southern inferiority with its alleged backwardness". ${ }^{20}$ In the LN's popular propaganda, the south is associated with Africa or described as having a Levantine culture. ${ }^{21}$ Indeed, it is the purported ethnic or racial divide, the fundamental difference in the nature of the people in question - the northerners perceived as a Celtic people, the southerners as a Mediterranean people that has informed the LN's attitudes to southerners and, subsequently, African immigrants as lazy and incapable. It is these qualities that purportedly distinguish the north's economic success and dynamism from the south's relative backwardness.

Gold observes that the LN "has been effective at presenting northern identity as a 'community of interests' that is threatened by a series of enemies ranging from

\footnotetext{
${ }_{17}$ Michael Huysseune, Modernity and Secession: The Social Sciences and the Political Discourse of the Lega Nord in Italy, New York and Oxford: Berghahn Books, 2006, p. 174.

18 ibid., p. 177.

19 Trendsetting/ Sondaggio Swg-Affaritaliani.it: gli italiani non credono nella Padania. Ma al Nord prevale il sì alla secessione, Lunedì, 28 giugno 2010 - 08:59:00, SWG Dipartimento Opinioni, Affari Italiani, 'Federalismo e

Secessione', Trieste, 25 giugno 2010, accessed 3 October 2012,

http://affaritaliani.libero.it/politica/padania_sondaggio_swg_secessione250610.html

${ }^{20}$ Huysseune, 2006, p. 177.

21 ibid.
} 
southerners and high taxes to the bureaucracy in Rome." ${ }^{22}$ In this endeavor, the LN has been assisted by "the fact that the diffusion of industrial districts has consolidated regional interests in the north within a tight-knit community". ${ }^{23}$ He notes that part of the LN's early success was its ability to mobilise an electorate with similar values pertaining to work ethic and entrepreneurship, as well as shared concerns about high taxes and bureaucratic red tape, which allowed them to seek a stronger voice for northern concerns. ${ }^{24}$ This strategy relied on the perpetuation of a distinct civil society in the north that warranted separate and distinct political representation. It was premised on the continuation of a fundamental divide between north and south.

There have obviously been alternative explanations for the enduring divide between the north and south of Italy that do not focus on the sort of racial profiling that the LN has undertaken in its popular propaganda. The possibility that Italian policies since unification, including the promotion of internal migration in the post-war period from south to north to fuel the emerging industrial economy of northern Italy, may have contributed to the south's economic woes does not feature at all in the LN's explanation of northern success and southern failure. Gold explains that the divide is partly attributable to the "specific actions of political elites": specifically, the "clientelist policies of the DC ... [involving] the trading of state resources for votes" resulting in "a dependent south that lacks many of the necessary resources to help autonomous growth and development". 25 Rather than viewing the south's economic problems and consequent dependency on the north as a case of institutional or governance failures or, alternatively, as a case of northern hegemony ${ }^{26}$ or of "uneven development or as a distinction between industrial and agrarian regional economies that grew as functions of geography and history" 27 - the LN's explanation assumes the racial superiority of the northerners vis-à-vis the southerners, although the party usually stops short (especially when addressing an intellectual or southern audience) of explicitly endorsing conceptions of "biological racism". ${ }^{28}$ Yet the LN's own efforts to draw the central Italian "northern periphery" into the Padanian territory underscores the true nature of the LN's project as a movement to aggregate the resources of an economically developed region which shares similar socioeconomic values. Padania as a geographical area remains heterogeneous and has no common history, but has nonetheless achieved relative wealth and economic strength.

The LN's previous attempts to enhance its influence by expanding the limits of its periphery held the seeds of disintegration, as the internal coherence of its claim of a common history, geography and culture was further diluted. The question now arises: can the LN remake itself as a national party privileging the value of "autonomy" wherever it may appear on the Italian peninsula, or will its foray into a national political space signal the demise of its function as a repository for northern pride and as a vehicle for the explicit promotion of northern interests and hegemony?

\footnotetext{
22 Gold, 2003, p. 10.

23 ibid.

24 ibid.

25 ibid., p. 123.

${ }^{26}$ Aprile, 2011.

27 Global South, 'Antonio Gramsci, the Lega Nord, and Italy's Southern Question', 23 November 2010, accessed 7 March 2015, http://globalsouth12.wordpress.com/antonio-gramsci-the-lega-nord-and-italy's-southern-question/ ${ }^{28}$ Huysseune, 2006, p. 178.
} 


\section{The LN as a Populist, Ethno-Regionalist Party}

It has been observed that the story of the LN is a complex one: it "cannot simply be reduced to the growth of an increasingly xenophobic electorate or a revolt of the rich regions". 29 The LN defies simple, one-dimensional characterisations. Thus Diamanti has defined it as, above all, federalist. $3^{\circ}$ Cento Bull and Gilbert have labeled it a populist but also an "ethno-regionalist" party. ${ }^{31}$ Nativist nationalism is another defining feature of the party. ${ }^{2}$ For its part, the LN presents itself as "supporting a neo-liberal revolution" in post-war Italian politics, and from this position it has successfully exploited anti-state and anti-party sentiments in Italy. 33 The party is now poised to exploit widespread anti-EU sentiment, as the Eurozone's trials and tribulations continue to erode public support for the EU. As a pragmatic and populist party the LN is moving closer to other radical right nationalist parties in Europe which have successfully exploited rising societal insecurity. Cento Bull and Gilbert correctly point out that:

The populist parties of the radical right ... have thriven upon the insecurity, displacement and psychological crises engendered by the pace of economic change and have had great success in attracting the votes of those groups which represent the losers in the changes brought about by the process of economic globalization. ${ }^{34}$

As predicted by Gold, "globalization and the territorial fissures it causes will also provide further fuel for inward looking, xenophobic parties like the Lega Nord." 35 Whether traditionally regionalist (like the LN) or nationalist (like the Front National in France), populist right wing parties have "mobilized a great deal of support by arguing that the current rise in free trade, immigration and multiculturalism is a threat to borders, whether national or regional". ${ }^{36}$ For Zaslove, the LN also espouses a populist political economy featuring support for the market economy and opposition to globalisation and the destruction of local, autochthonous communities. 37 In all of these representations, the nexus between the LN and populism is established. So how is populism defined?

A highly ambiguous and often confusing term, populism has been applied to a variety of political movements, some of which have espoused radical ideologies while others have been somewhat conservative "catch-all parties". ${ }^{8}$ For many liberals and democrats, populism represents a "political tendency which panders to the reactionary and xenophobic instincts of the grass roots, instigating them against the intellectual elites".39

\footnotetext{
29 Gold, 2003, p. 7.

30 Ilvo Diamanti, 'L'improbabile ma rischiosa secessione' Il Mulino, 5/95, 1995: p. 816.

${ }^{31}$ Anna Cento Bull and Mark Gilbert, The Lega Nord and the Northern Question in Italian Politics, Houndmills: Palgrave, 2001, p. 48 (citing Biorcio).

$3^{2}$ Zaslove, 2011, p. 108.

33 ibid., p. 133.

34 Cento Bull and Gilbert, 2001, p. 48.

35 Gold, 2003, p. 129.

36 ibid., pp. 129-130.

37 Zaslove, 2011, p. 15.

${ }^{8}$ Cento Bull and Gilbert, 2001, p. 45.

39 ibid., p. 46 (citing Canovan).
} 
Studies on populism have stressed a number of recurring elements in popular movements:

1. a constant reference to 'the people' framed as 'an organic and homogenous community' sharing common values;

2. a so-called 'populism of the little man' representing the values and beliefs of small proprietors who dislike big business and big government and liberal moral values;

3. a charismatic leader;

4. a rhetoric of anti-elitism, a dislike of politicians and proneness to conspiracy theories; and

5. a strong tendency towards racism. ${ }^{40}$

The LN ticks all of the categories of populism identified above, from the party's trenchant criticism of political elites to its strong tendency towards racism, as well as the central role of its charismatic leaders (first Bossi, then Salvini).

By attributing inordinate value to the racial, ethnic and cultural traits that purportedly distinguish Padanians from others, the $\mathrm{LN}$ is creating a cultural milieu inimical to solidarity among the different peoples within the territory. Indeed, the LN has profited from the societal unease that usually accompanies the arrival of large numbers of immigrants in traditionally homogeneous societies, its anti-immigrant, populist rhetoric striking a chord with many Italians. Italy is currently host to approximately $5,800,000$ regular migrants, $9.7 \%$ of the total population, while the annual growth rate of migrant presence is among the highest in the EU.41

Irregular migration represents an even greater source of anxiety. In 2014, 170,100 asylum seekers arrived on Italian shores, $4^{2}$ most of them on the Sicilian Island of Lampedusa. In November 2014, violence towards immigrants erupted in one of Rome's poorest suburbs, Tor Sapienza. Illegal immigrants and asylum seekers had been arriving in this area for some time. Their presence had become increasingly visible and contentious, as many of the 170,000 irregular migrants rescued by the Italian navy in the Mare Nostrum operation in 2014 alone converged on the suburb. Local residents protested angrily about increasing neglect from the Italian state in the face of rising unemployment and violent crime. Many residents blamed refugees and immigrants for their plight as they lamented the support (albeit meager) that refugees were extracting from the already financially burdened state: money that would otherwise have flowed to them. While the eruption of anger appears rooted in racism and xenophobia, it also coincides with vanishing hope in the poorer areas of Italy's and Europe's large cities. It is this sentiment that plays into the hands of the LN and other extremist parties and movements on the right and left of the political spectrum.

The LN may be accused of feeding the cultural attitudes that presage racism and human rights infringements, although the $\mathrm{LN}$ rejects all charges of racism. This denial is not easily reconciled with assertions such as that of its former leader, Umberto Bossi, the Minister of Devolution in 2003, who stated that "Padanians did not work the land

\footnotetext{
40 ibid.

${ }^{41}$ International Organization for Migration (IOM), 'Global Migration Flows: Italy, Facts and Figures' Updated to September 2014,, https://www.iom.int/countries/italy,

42 International Organization for Migration (IOM), 'Migrant Arrivals by Sea in Italy Top 170,00o in 2014', 16 January 2015, accessed 7 March 2015, https://www.iom.int/cms/en/sites/iom/home/news-and-views/pressbriefing-notes/pbn-2015/pbn-listing/migrant-arrivals-by-sea-in-italy.html
} 
for thousands of years to give it away to Bingo Bongo and the Chinese". 43 Nor can it be reconciled with a remarkable claim made in July 2013 by one of the LN's leaders, Roberto Calderoli, that Cecile Kyenge, the Congo-born Integration Minister in Gianni Letta's government, reminded him of an orangutan. Amid calls for his resignation as deputy president of the Senate, Calderoli held his ground and insisted that the remarks were not racist. Calderoli won the support of senators, who ruled in February 2015 that the comments do not amount to racial hate. 44 The fact that he remains in his position at the will of the Senate arguably reflects poorly on Italian politics and its refusal to chastise a leading politician whose comments promote adverse cultural attitudes to the promotion of respect for diversity and human dignity in an increasingly divided Europe.

In Italy, Law 205 of 1993, commonly referred to as the Mancino Law, prosecutes acts of incitement to racial violence and the propagation of ideas based on racial superiority or racial or ethnic hatred. It is also a crime to facilitate the activity of organisations, associations, movements, or groups that have this purpose among their objectives. Though rare, there have been convictions against politicians for hate speech under the law. On 2 December 2004 six elected representatives of the LN (then part of the national governing coalition) were convicted of racial hate speech by the first instance court of Verona for a campaign perpetrated against the members of the local Sinti community in September 2001. The defendants were sentenced to six months imprisonment, ordered to pay $€ 45000$ in damages and were prohibited from taking part in electoral campaigns for three years. This decision gave rise to demands from the LN and other right wing groups for the abolition of the rules on hate speech contained in the Mancino Law. 45 The Mancino Law has undergone numerous amendments since its introduction. ${ }^{46}$ In January 2006, at the request of the LN, the Italian Parliament adopted an act which significantly weakened the penalties for hate speech and the instigation to racial discrimination.47 The RED Network Early Warning System 48 reports that the "Lega Nord frequently uses racist and anti-Romani language in public statements". Furthermore, the European Roma Rights Centre (ERRC) has

\footnotetext{
43 Joao Carvalho, Impact of Extreme Right Parties on Immigration Policy: Comparing Britain, France and Italy, London and New York: Routledge, 2014, p. 132.

44 The Local, 'Not racist to call black person orangutan', 6 February 2015, accessed 8 February 2015, http://www.thelocal.it/20150206/calling-a-black-person-orangutan-not-racist-senate

45 European Anti-Discrimination Law Review, Issue No. 1, April 2005, accessed 7 March 2015, http://ec.europa.eu/justice/discrimination/files/lawrev1_en.pdf, p. 59.

${ }^{4}$ Amendments have been made to also include gender and religious affiliation. The most recent proposal for change covered lesbian, gay and transgender rights. The proposal was to make it an offence to instigate or commit discrimination or acts of violence on the grounds of "homophobia or transphobia". The final version of the bill, approved in September 2013, included a key amendment. The amendment, known as the Gitti amendment, after its initiator Gregorio Gitti of Scelta Civica (the party established by former PM Mario Monti), states that the expression of opinion in the context of political, cultural, religious, educational organisations, does not constitute discrimination so long as it does not incite to violence. This change has been criticised for its vague wording and its nebulousness and for glossing over discrimination at the hands of organisations. See: Isotta Rossoni, 'The Scalfarotto Law and LGBT Rights in Italy', One Europe, 30 September 2014, accessed 23 February 2015, http://one-europe.info/lgbt-rights-italy

47 RED Network, Indicator history 2011, 'Nationwide organisations that express racist or xenophobic sentiments/discourse' accessed 23 February 2015, http://www.red-network.eu/indicator-countryhistory? $\mathrm{id}=11 \&$ iid $=36$

${ }^{48}$ The RED Network, is an independent research network building the RED early warning system composed of 17 Research and Civil Society Organisations in EU Member States. It aims at reporting and documenting racist and hate crime and discrimination incidents, as well as positive initiatives and policy responses. RED Network, 'Monitoring Extremism: European Hate Crime Early Warning System', 2012, accessed 23 February 2015, http://www.red-network.eu/?i=red-network.en.about-us
} 
reported "a disturbing pattern of racist and anti-Romani speech by Italian public officials" with specific reference to the LN.49

Thus, the LN's rejection of the accusation of racism and xenophobia has no foundation in fact. It is apparent that the personal hardships and struggles of immigrants are not assimilated within the LN's consciousness, which seems to remain aloof from the transformative effects of human interaction and shared experience, at least at the level of rhetoric. 50

\section{The Post-Bossi era}

On 5 April 2012, Bossi resigned as Federal Secretary of the party (a position he had held since the party's establishment in 1991) in the midst of a scandal in which the party's treasurer was accused of fraud and illegal party financing. The scandal dealt a potentially fatal blow to a party founded as a protest movement against fraud and corruption in the Italian political system, a point not lost on its opponents. In the face of Bossi's resignation, an interim team of party leaders - Roberto Calderoli, Roberto Maroni and Manuela Dal Lago - was appointed to lead the party, but Bossi's resignation signaled a possible transition from idiosyncratic movement into something much more common on the Italian and European political scene. The Lega suffered a significant loss of electoral support in the 2013 national elections, but has since reversed its electoral fortunes. The election of Matteo Salvini as party leader in 2013, a shift of focus from secession to anti-euro and anti-immigrant (especially Muslim) positions, and a highly visible alliance with France's Front National have proved effective in rebuilding the LN's electoral appeal, as evidenced by the 2014 regional election result in Emilia Romagna. At the time of writing, Matteo Salvini was Italy's second most popular political leader, only marginally behind Prime Minister Matteo Renzi.

In the context of a rapidly changing society and shifting political prospects, Salvini has fashioned a new message capable of being accepted by a national audience, in belated recognition that southern Italians also vote. To be sure, the message is neither positive nor edifying. It is still born of xenophobia and supremacism, and responds to populist concerns about globalisation, loss of identity and various manifestations of insecurity. Now, however, the vitriol appears to be aimed at non-Italians, non-Europeans and the EU. Devoid of anti-Italian sentiment, this new message, which focuses hostility on immigrants, the euro, austerity and the EU, is likely to resonate in every corner of a country experiencing economic decline and societal insecurity. Whether southern Italy will respond positively to the message in the short term is doubtful. The process of recasting policies and winning new allegiances in the south is no doubt a medium to long-term project.

\section{The LN within a European Dynamic}

A softening of the LN's traditional anti-southern position indicates a will to reach beyond its heartland and shift towards a more national platform and a common enemy

\footnotetext{
49 European Roma Rights Centre, 'Campland: Racial Segregation of Roma in Italy', 3 November 200o, accessed 23 February 2015, http://www.errc.org/article/campland-racial-segregation-of-roma-in-italy/224

$5^{\circ}$ The LN claims success in its governance of cities such as Verona and Treviso with large immigrant populations. However, as long as immigrants remain outside the party's compass (actual or perceived) there can be no claim to representation of all social groups or to social justice, as representation can only be partial.
} 
in Brussels. A wave of anti-immigrant, anti-EU sentiment has seen the further rise of far right populist political parties and movements across Europe. Rascism and xenophobia are on the increase, presenting real challenges for social cohesion in numerous member states of the EU. These challenges threaten to reverse the positive cultural effects cultivated through more than half a century of European integration. Similarly, negative sentiment for austerity - insisted upon by Brussels and Berlin - is playing into the hands of populists in Greece, Italy, France and elsewhere. Austerity is sowing the seeds of discontent and reaping bitter harvests, as seen during the Greek referendum crisis. Trust in EU institutions has been evaporating for some time. ${ }^{11}$ Eurosceptics throughout the EU are conflating the economic woes in their countries with the loss of sovereignty and/or the euro. $5^{2}$ Populists in many member states are presenting an alternative vision of European cooperation based on the privileging of narrowly construed national over communitarian values and a preference for exclusion rather than inclusion.

In Italy, the LN, Casa Pound and other anti-immigrant parties are gaining support for their policies of exclusion in the face of increasing economic pain inflicted by the economic crisis. This is not solely an Italian phenomenon, as indicated above. The political fortunes of far right political parties in many Eurozone countries have improved as a result of the crisis, as the Front National in France and Golden Dawn in Greece, among others, demonstrate.53 The popularity of Golden Dawn, a party at the extreme end of the spectrum, has increased with the spread of hardship under the rigid austerity demanded by the EU in response to the financial crisis. 54 Golden Dawn has been in existence since the mid-1980s, but it has only become a force in Greek politics since the onset of the crisis in 2010. Outside of the Eurozone, the effects of the sovereign debt crisis and growing disenchantment with the EU have propelled support for nationalist parties such as the United Kingdom Independence Party (UKIP) and Hungary's radical nationalist Jobbik upwards. 55 The EU brand is now blemished and populist parties are seeking to benefit from rising disenchantment with the EU. Their capacity to influence national politics has risen exponentially since the emergence of the crisis. Not coincidentally, the LN has adopted a strategy towards Europe that aligns more closely to the nationalist politics of its far-right counterparts in Europe.

The LN's repositioning vis-à-vis the EU is all the more remarkable because, until recently, its position on Europe was one of strong support, especially for its focus on regional governance. The EU's regional policy showcased an attractive model of

\footnotetext{
${ }^{51}$ Citizens have been losing faith in the EU for some time. The Standard Eurobarometer 81 Report, measuring public opinion in the EU in Spring 2014, showed that the unpopularity of the European institutions (European Parliament, European Commission and European Central Bank) had reached new highs (Eurobarometer 81, Spring 2014: pp. 88-89). "The EU is perceived by a majority of Europeans as being over-bureaucratic, responsible for austerity, unfair and ineffective in tackling what Europeans consider as two key issues, namely employment and purchasing power" (Eurobarometer 81, Spring 2014: p. 104).

$5^{2}$ Michael Longo and Philomena Murray, The European Union's Legitimacy Crisis: From Causes to Solutions, Houndmills: Palgrave Macmillan, 2015.

53 Greece's far-right, anti-immigrant Golden Dawn party came third in the January 2015 national election with 6.3\% of the vote, even though its leaders are in detention. See Peter Laurence, "Greek Elections: Jail fails to deter far-right Golden Dawn”, Inside Europe Blog, BBC News, 26 January 2015, accessed 23 February 2015, http://www.bbc.com/news/blogs-eu-30980002

54 ibid.

55 Harold D. Clarke notes the agenda setting potential of UKIP: "As election campaign kicks off, UKIP is setting the agenda", The Conversation, 3 February 2015, accessed 23 February 2015, http://theconversation.com/aselection-campaign-kicks-off-ukip-is-setting-the-agenda-35802. In the Hungarian parliamentary elections in April 2014, the Jobbik party polled over one million votes securing $21 \%$ support, making them Hungary's third largest party in the national assembly. See Eszter Zalan, "Hungary's Orban wins another term, Jobbik support jumps", euObserver, 7 April 2014, accessed 23 February 2015, https://euobserver.com/eu-elections/123762
} 
regional engagement with Brussels, which potentially allowed the LN to bypass the Italian state and interact directly with the EU. The practice of cross-border collaboration with like regions across the Alps on a range of regional policy programmes in the areas of environmental management, rural development, governance, education and culture ${ }^{56}$, among others, held the added promise of realignment with other European peoples, with whom the LN claims to share a common heritage, on its own terms.

The LN's favourable orientation to the EU has been transformed into trenchant opposition to the EU's monetary and economic governance and its inactivity on immigration. Salvini has called the euro "a crime against mankind". $57 \mathrm{He}$ criticises the EU for its failure to intervene effectively on the immigration crisis, which allegedly poses a societal and security threat to Italy. In so doing, the LN has aligned itself with a strongly performing Front National in France. ${ }^{8}$ However, unlike Marine Le Pen's Front National, Geert Wilders' Freedom Party in the Netherlands or Nigel Farage's UKIP in the United Kingdom, the LN is traditionally constrained by a lack of a national platform across the full range of policy areas. With a few high profile exceptions (e.g. the island of Lampedusa), the LN has very limited support in the south or, indeed, in most regions beyond its heartland. This constraint has come into clearer focus with the emergence of Front National as a significant political force in France and a strong political force in Europe. The LN's traditional policies on Padanian independence and federalism, as well as its anti-southern rhetoric, have worked to differentiate the LN from Le Pen's party.

While the LN's slogan "Prima il nord" echoes on one level the nationalist/supremacist ethos of Le Front, the context differs markedly. Within the Italian political context, the LN's message of independence is anything but nationalist. Indeed, independence and anti-southern rhetoric restrain the LN's electoral viability as a national force, even if these policies retain their popularity in northern Italy. To be sure, the independence of Padania has conveniently been emphasised or de-emphasised by the $\mathrm{LN}$ according to political exigencies. The $\mathrm{LN}$ is currently assessing the independence of Padania as dispensable. As long as the LN represents only the north and bordering communities in the centre, it cannot entertain the aspirations of a Le Pen, Wilders or other populist leaders in Europe. The LN's penchant for opportunistic shifts in direction suggests that a major shift is in the offing. With the launch of the LN's counterpart in Lazio, southern Italy and Sardinia Noi con Salvini (NcS) (Us with Salvini), and the associated apology to the south,59 a shift in the narrative of identity and belonging has been invoked.

\footnotetext{
${ }^{56}$ See for instance European Commission Regional Policy, Cohesion Policy 2007-2013, 'Cross-border programmes under the European Territorial Cooperation Objective' accessed 3 March 2015, http://ec.europa.eu/regional_policy/atlas2007/eu/crossborder/index_en.htm 57 'Lega, Salvini contro euro: "Crimine contro L'umanitá”, , Ansa, 15 December 2013, accessed 6 June 2014, http://www.ansa.it/web/notizie/rubriche/politica/2013/12/15/Lega-Salvini-contro-euro-Crimine-controumanita-_9781968.html

${ }^{8}$ Le Pen's Front National emerged from the EP vote as France's first party, winning 73 electoral departments, while President Hollande's socialists were thoroughly thrashed. Ambrose Evans-Pritchard, 'Europe has an even bigger crisis on its hands than a British exit,' The Telegraph, 28 May 2014, accessed 6 June 2014,

http://www.telegraph.co.uk/finance/comment/ambroseevans_pritchard/10861252/Europe-has-an-even-biggercrisis-on-its-hands-than-a-British-exit.html

59 Salvini offered an apology for the Lega's past rhetoric towards the south: "Salvini tra contestazione e applausi a Palermo: "Chiedo scusa ai meridionali se li ho offesi"”, La Stampa Politica, 8 February 2015, accessed 8 February 2015, http://www.lastampa.it/2015/02/o8/italia/politica/palermo-salvini-va-in-cerca-di-voti-ma-trova-lacontestazione-mobnJTwbkV16kTReCbwaRP/pagina.html
} 


\section{Conclusion}

The LN has endured on the ever-changing Italian political scene for almost 25 years under the same name 60 and political message, with only minor variation. It is now Italy's oldest and third largest party, behind Matteo Renzi's Democratic Party and Beppe Grillo's Movimento 5 Stelle. There is a strong chance that the LN will continue to outperform Berlusconi's centre-right party, Forza Italia, a party riven by internal division. Any future coalition between the two parties will highlight the growing political resources of the LN. No doubt the LN sees opportunity in the current constellation of anti-government, anti-Berlusconi, anti-Euro, anti-austerity, antiimmigrant and anti-EU sentiment. The LN's anti-immigrant message is now directed squarely at non-EU immigrants in an attempt to neutralise southern indignation, while its current stance towards the EU allows it to capitalise on growing distrust of EU institutions and economic governance.

The softening of the LN's traditional hostility towards the south and its people previously characterised as lazy, incapable, backward and prone to criminality ${ }^{61}-$ represents an accommodation of the tensions that have wracked north-south relations in Italy since the emergence of Bossi's LN in the early 1990s. The LNs change of direction towards a national profile may be understood within the catalogue of changes apparent in party-based systems within Europe, whereby parties seek direct engagement between citizens and institutions on terms that achieve the most immediate electoral gains. These terms may be described as populist. Therefore, the LN has tempered its anti-southern rhetoric in recognition that the south represents a hitherto untapped opportunity for growth.

In spite of Salvini's overtures to the south, there will be multiple hurdles in trying to overcome decades of hostility between the $\mathrm{LN}$ and ordinary voters in the south. The establishment in December 2014 of NcS was met with interest and distrust in equal measure. Attempts to organise cartels of politicians sympathetic to Salvini in Sicily and the rest of southern Italy will be hampered by the prevalence of popular resentment towards him and his party, as well as an ongoing militant debate on southern identity (Infoaut 2015), which increasingly acts as a counterweight to popular, LN-inspired representations of northern identity. For now, the south remains largely closed to the LN's anti-immigrant, anti-EU cues. Nonetheless, recent national opinion polls have tended to show the LN and NcS as the third force in Italian politics, ahead of Berlusconi's Forza Italia. ${ }^{62}$ This demonstrates that Salvini's "national project" is resonating with voters.

The LN's national project will catapult the LN into the same congested political space occupied by a plethora of Italian political parties, large and small. It is likely that internal divisions within the $\mathrm{LN}$ and between the LN and its sister party, $N c S$, will emerge. It is apparent that the LN is currently well placed to distinguish itself from

\footnotetext{
${ }^{60}$ Italian political parties seem to regularly change their name, whenever a new beginning is perceived to be necessary or in response to changing political allegiances.

${ }^{61}$ These and similar polarising caricatures of southern Italians have actually been a mainstay of northern propagandists' analysis of the “Southern Question" since the country's unification in 1861. See for example, Aprile, 2011, pp. 255-288. See also Global South, 2010.

62 For example, see Datamedia Poll, 18 March 2015, accessed 2 April 2015,

http://scenaripolitici.com/2015/o3/sondaggio-datamedia-18-marzo-2015-csx-414-91-cdx-323-m5s-195.html; Euromedia Poll, 17 March 2015, accessed 2 April 2015, http://scenaripolitici.com/2015/o3/sondaggioeuromedia-17-marzo-2015-csx-409-6-cdx-349-m5s-186.html; Piepoli Poll, 16 March 2015, accessed 2 April 2015 , http://scenaripolitici.com/2015/o3/sondaggio-piepoli-16-marzo-2015.html
} 
most other parties by a set of policies that reflects the societal insecurity sweeping European societies. However, at some point the $\mathrm{LN}$ will need to reassess its raison d'être.

The LN will eventually face a stark choice. Representing a predominantly northern constituency will satisfy the party's grassroots, but will preclude the emergence of a national party capable of attracting a new constituency of newly poor, marginalised and insecure Italians disenchanted with mainstream national politics, the EU and the negative effects of globalisation. On the other hand, to loosen the ties of heritage may hold the risk of widespread resentment and voter backlash among the grassroots party faithful. The LN has previously moderated its policy on independence because that policy held the seeds of destruction for the LN. It polarised supporters rather than united them, and clouded their identity. It also precluded power sharing in governing coalitions. What the LN does about its position on independence will reveal its longterm ambitions and prospects.

The LN is on a path to achieving national prominence. Its current approach of organising cartels of interested southern politicians to advance its national agenda is open to discussion. How effective this will be in convincing southern Italians of the genuineness of the Lega's national project remains to be seen. Nonetheless, there is an incipient dilemma in the LN's current trajectory which holds the seeds of growth and of destruction for the LN. One way or another, the LN will be transformed and so, too, will Italian society. 